\title{
Analisis sektor unggulan di Kabupaten Batanghari
}

\author{
Andi Syaputra*; Hardiani; Adi Bhakti \\ Prodi Ekonomi Pembangunan, Fakultas Ekonomi dan Bisnis, Universitas Jambi \\ *E-mail korespondensi: andisyaputra1421@gmail.com
}

\begin{abstract}
This study aims to analyze the leading sectors in the economy in Batanghari Regency. This study uses secondary data for the period 2011-2017, sourced from the Central Statistics Agency of Jambi Province and Batanghari Regency. The analysis tools used are Location Quotient (LQ) analysis and Shift Share analysis. The results of the study found that the leading sectors in Batanghari Regency are the manufacturing industry sector, the government administration sector, defense, compulsory social security, and the education service sector.
\end{abstract}

Keywords: Leading sector, Location quotient, Shift share

\begin{abstract}
Abstrak
Penelitian ini bertujuan untuk menganalisis sektor unggulan dalam perekonomian di Kabupaten Batanghari. Penelitian ini menggunakan data sekunder periode tahun 20112017, yang bersumber dari Badan Pusat Statistik Provinsi Jambi dan Kabupaten Batanghari. Alat analisis yang digunakan yaitu analisis Location Quotient (LQ) dan analisis Shift Share. Hasil penelitian menemukan bahwa sektor unggulan di Kabupaten Batanghari adalah Sektor industri pengolahan, Sektor administrasi pemerintahan, pertahanan dan jaminan sosial wajib dan Sektor jasa pendidikan.
\end{abstract}

Kata kunci: Sektor unggulan, Location quotient, Shift share

\section{PENDAHULUAN}

Pertumbuhan ekonomi adalah salah satu tolak ukur yang dapat dipakai untuk meningkatkan adanya pembangunan suatu daerah dari berbagai macam sektor ekonomi yang secara tidak langsung menggambarkan tingkat perubahan ekonomi. Menurut Sukirno (2008), pertumbuhan ekonomi berarti perkembangan kegiatan dalam perekonomian yang menyebabkan barang dan jasa yang diproduksikan bertambah dan kemakmuran masyarakat meningkat. Sektor-sektor ekonomi yang masuk dalam komponen produk domestik regional bruto adalah sektor pertanian, sektor pertambangan dan penggalian, sektor industri pengolahan, sektor listrik, gas dan air bersih, sektor bangunan, sektor pengangkutan dan komunikasi, sektor keuangan, persewaan dan perusahaan, sektor jasa-jasa. Berkaitan dengan struktur ekonomi wilayah, Todaro (2000) menyatakan bahwa proses pertumbuhan ekonomi mempunyai kaitan erat dengan perubahan struktural dan sektoral yang tinggi.

Pelaksanaan otonomi daerah dengan pemberdayaan potensi daerah akan bisa berjalan jika sektor unggulan daerah dapat dioptimalkan. Sektor unggulan tersebut adalah sektor yang memenangkan persaingan dibandingkan dengan sektor lainnya (Yuwono, 1999). PDRB merupakan indikator penting di suatu wilayah yang dapat menginditifikasikan totalitas produksi neto barang dan jasa yang selanjutnya dapat digunakan sebagai dasar perencanaan dan evaluasi pembangunan wilayah. PDRB 
berperan sebagai pengukur tingkat pendapatan bruto yang berada dalam suatu Provinsi. PDRB yang selalu menurun menyebabkan ketidakpastian bagi pembangunan di daerah dan kesejahteraan masyarakat. Suatu masyarakat dipandang mengalami suatu pertumbuhan dalam kemakmuran masyarakat apabila pendapatan perkapita menurut harga atau pendapatan terus menerus bertambah. Pembangunan didaerah akan menurun jika PDRB selalu menurun tiap tahunnya.

Permasalahan utama dalam suatu daerah dalam pelaksanaan pembangunan adalah kurang mampunyai pemerintah daerah dalam pelaksanaan strategi perencanaan yang matang dan kurang telitinya melihat potensi daerah tersebut. upaya dalam peningkatan pembangunan ekonomi adalah perlu penetapan sektor unggulan sebagai sektor basis daerah yang kemudian akan menjadi tutuk pertumbuhan daerah serta melihat bagaimana laju dan daya daya saing sektor-sektor perekonomian, dengan demikian diharapkan akan tumbuh dan berkembang daerah-daerah sebagai pusat pertumbuhan nasional sehinggga pada akhirnya daerah akan menjadi tulang punggung perekonomian nasional. Apabila sektor yang memiliki keunggulan komparatif bagi suatu daerah telah teridentifikasi maka pembangunan sektor tersebut dapat disegerakan tanpa menunggu tekanan mekanisme pasar yang sering berjalan terlambat (Tarigan, 2004).

Laju pertumbuhan tiap sektor terhadap PDRB di Kabupaten Batanghari dari tahun ke tahun terlihat naik turun, bahwa sektor Pertanian menurun ditahun 2015-2017 jika di bandingkan tahun 2014, sedangkan sektor Perdagangan Besar dan Eceran; Reparasi Mobil dan Sepeda Motor menunjukkan perkembangan tiap tahunnya walaupun tidak secara signifikan. Untuk laju pertumbuhan per sektor tertinggi terjadi pada sektor Pertambangan dan Penggalian yaitu sebesar 13,47 pada tahun 2017. Adapun sektor dengan laju pertumbuhan ekonomi paling lambat di Kabupaten Batanghari pada tahun 2017 adalah sektor jasa keuangan dan asuransi yaitu sebesar 2,38 persen.

Berdasarkan latar belakang tersebut, penelitian ini bertujuan untuk menganalisis: 1) Untuk mengetahui dan menganalisis sektor unggulan di Kabupaten Batanghari., 2) Untuk mengetahui sektor potensial sebagai penunjang pertumbuhan ekonomi di Kabupaten Batanghari

\section{METODE}

\section{Jenis dan sumber data}

Data pokok yang digunakan dalam penelitian ini merupakan data sekunder, berupa PDRB Kabupaten Kerinci dan Provinsi Jambi Tahun 2011-2016. Data diperoleh dari Badan Pusat Statistik (BPS) Kabupaten Kerinci dan Provinsi Jambi.

\section{Metode analisis data}

\section{Location qountient (LQ)}

LQ adalah indikator sederhana yang menunjukkan kekuatan atau besar kecilnya peranan suatu sektor dalam suatu daerah dibandingkan dengan daerah diatasnya. Menurut Arsyad (1999) bahwa teknik Location Quotient dapat membagi kegiatan ekonomi suatu daerah menjadi dua golongan yaitu basis dan non-nasis. Berkaitan dengan tujuan penelitian, dalam mengukur LQ menggunakan pendekatan nilai tambah atau PDRB (Tarigan, 2009) adalah sebagai berikut:

$$
L Q=\frac{V_{i / V_{t}}}{Y i / Y_{t}}
$$


Keterangan:

Vi : Nilai PDRB sektor i pada tingkat wilayah yang lebih rendah

$\mathrm{Vt} \quad$ : Total PDRB pada tingkat wilayah yang lebih rendah

Yi : Nilai PDRB sektor i pada tingkat wilayah yang lebih atas

Yt : Total PDRB pada tingkat wilayah yang lebih atas

LQ $>1$ : Sektor basis

$\mathrm{LQ}=1:$ Sektor sama dengan daerah lain

LQ $<1:$ Sektor non basis

i : 1. Pertanian, kehutanan, dan perikanan, 2. Pertambangan dan penggalian

3. Industri pengolahan, 4. Pengadaan listrik dan gas, 5. Pengadaan air, pengelolaan sampah, limbah dan daur ulang 6.Kontruksi 7. Perdagangan besar dan eceran; reparasi mobil dan sepeda motor, 8. Transportasi dan pergudangan, 9. Pennyediaan akomodasi dan makan minum, 10. Informasi dan komunikasi, 11. Jasa keuangan dan asuransi, 12. Real estate, 13, Jasa perusahaan, 14. Administrasi pemerintahan, pertallanan dan jaminan sosial waiib, 15. Jasa pendidikan, 16. Jasa kesehatan dan kegiatan sosial, 17. Jasa lainnya

\section{Shift share}

Analisis shift share merupakan salah satu teknik kuantitatif yang biasa digunakan untuk menganalisa perubahan struktur ekonomi daerah relatif terhadap struktur ekonomi wilayah administrasi yang lebih tinggi sebagai pembanding atau referensi.

Metode Analisis shiftt share diawali dengan perubahan nilai PDRB suatu sektor (i) antara dua periode, yaitu periode tahun dasar o dan periode t. Metode ini didasarkan pada asumsi dasar bahwa pertumbuhan ekonomi suatu daerah dipegaruhi oleh tiga komponen utama yaitu: a) Pertumbuhan nasional, b) Pertumbuhan sektoral dan c) Pertumbuhan daya saing wilayah Kabupaten Batanghari.

Menurut Soepomo (1993) analisis shift share dapat dirumuskan sebagai berikut: $\mathrm{Dij}=\mathrm{Nij}+\mathrm{Mij}+\mathrm{Cij}$. Bila analisis itu diterapkan pada pendapatan, yang dinotasikan dengan $\mathrm{y}$, maka $\mathrm{Nij}=\mathrm{Yij}$. rn

Mij = Yij (rin-rn)

$\mathrm{Cij}=$ Yij(rij-rin)

$\mathrm{Rij}=(\mathrm{Y} * \mathrm{ij}-\mathrm{Yij}) / \mathrm{Yij}$ rin $=\left(\mathrm{Y}^{*} \mathrm{in}-\mathrm{Yin}\right) / \mathrm{Yin}$

Keterangan:

Dij : Pergeseran (selisih) PDRB sektor i di wilayah j Kabupaten Batanghari

Nij : Komponen pertumbuhan regional pada sektor i di wilayah j Kabupaten Batanghari

Mij : Komponen pertumbuhan proporsional pada sektor i di wilayah j Kabupaten Batanghari

Cij : Komponen keunggulan kompetitif sektor i di wilayah j Kabupaten Kerinci

Yij : PDRB sektor i di wilayah j Kabupaten Kerinci

Yin : PDRB sektor i di wilayah $n$ Provinsi Jambi

rn : Laju pertumbuhan keseluruhan pada wilayah dan Provinsi Jambi

rin : Laju pertumbuhan sektor i pada wilayah n Provinsi Jambi

rij : Laju pertumbuhan sektor i pada wilayah j Kabupaten Kerinci

i : 1. Pertanian, kehutanan, dan perikanan, 2. Pertambangan dan penggalian

3. Industri pengolahan, 4. Pengadaan listrik dan gas, 5. Pengadaan air, pengelolaan sampah, limbah dan daur ulang 6.Kontruksi 7. Perdagangan besar dan eceran; reparasi mobil dan sepeda motor, 8 . Transportasi dan pergudangan, 9. Pennyediaan akomodasi dan makan minum, 10. Informasi dan komunikasi, 11. Jasa keuangan 
dan asuransi, 12. Real estate, 13, Jasa perusahaan, 14. Administrasi pemerintahan, pertallanan dan jaminan sosial waiib, 15. Jasa pendidikan, 16. Jasa kesehatan dan kegiatan sosial, 17. Jasa lainnya

Menurut Sjafrizal (2008) komponen-komponen pada analisis shif share dapat diasumsikan sebagai berikut:

$\mathrm{Nij}=$ Apabila bernilai positif memiliki makna bahwa sektor pada wilayah tersebut tumbuh lebih cepat dari pada pertumbuhan sektor di wilayah atasnya.

Mij= Apabila bernilai positif mengindikasikan bahwa sektor di wilayah tersebut merupakan sektor yang maju dari pada sektor di wilayah atasnya.

$\mathrm{Cij}=\quad$ Apabila menunjukkan daya saing yang dimiliki suatu sektor pada wilayah tertentu dibandingkan dengan sektor yang sama pada wilayah di atasnya.

\section{HASIL DAN PEMBAHASAN}

\section{Analisis sektor basis pertumbuhan ekonomi Kabupaten Batanghari}

Analisis Location Quotient (LQ) digunakan untuk mengetahui sektor-sektor ekonomi dalam PDRB yang dapat digolongkan ke dalam sektor basis dan non basis. LQ merupakan suatu perbandingan tentang besarnya peranan suatu sektor di Kabupaten Batanghari terhadap besarnya peranan sektor tersebut di tingkat Provinsi Jambi. Nilai LQ $>1$ berarti bahwa peranan suatu sektor di Kabupaten Batangahri lebih dominan dibandingkan sektor di tingkat Provinsi Jambi dan sebagai petunjuk bahwa terjadi surplus akan produk sektor tersebut. Hasil perhitungan analisis LQ disajikan pada tabel 1 berikut:

Tabel 1 Hasil Perhitungan $L Q$ Kabupaten Batanghari Tahun 2011-2017

\begin{tabular}{cccccccccc}
\hline \multirow{2}{*}{ Sektor } & \multicolumn{7}{c}{ Tahun } & \multirow{2}{*}{ Rata-Rata LQ } \\
\cline { 2 - 7 } & $\mathbf{2 0 1 1}$ & $\mathbf{2 0 1 2}$ & $\mathbf{2 0 1 3}$ & $\mathbf{2 0 1 4}$ & $\mathbf{2 0 1 5}$ & $\mathbf{2 0 1 6}$ & $\mathbf{2 0 1 7}$ & & \\
\hline 1 & 1,61 & 1,55 & 1,53 & 1,54 & 1,53 & 1,50 & 1,45 & 1,53 & Basis \\
2 & 0,50 & 0,58 & 0,61 & 0,57 & 0,57 & 0,58 & 0,64 & 0,58 & Non-basis \\
3 & 1,13 & 1,11 & 1,11 & 1,13 & 1,13 & 1,13 & 1,13 & 1,12 & Basis \\
4 & 0,99 & 0,97 & 0,90 & 0,90 & 0,92 & 0,95 & 0,99 & 0,94 & Non-basis \\
5 & 0,59 & 0,59 & 0,60 & 0,59 & 0,60 & 0,59 & 0,63 & 0,60 & Non-basis \\
6 & 1,05 & 0,98 & 0,95 & 0,93 & 0,95 & 0,97 & 0,94 & 0,97 & Non-basis \\
7 & 0,84 & 0,81 & 0,81 & 0,80 & 0,78 & 0,79 & 0,79 & 0,80 & Non-basis \\
8 & 0,51 & 0,51 & 0,49 & 0,48 & 0,48 & 0,47 & 0,46 & 0,48 & Non-basis \\
9 & 0,34 & 0,32 & 0,31 & 0,33 & 0,34 & 0,34 & 0,35 & 0,33 & Non-basis \\
10 & 0,83 & 0,82 & 0,81 & 0,81 & 0,80 & 0,79 & 0,79 & 0,80 & Non-basis \\
11 & 0,86 & 0,84 & 0,84 & 0,83 & 0,83 & 0,81 & 0,80 & 0,83 & Non-basis \\
12 & 0,89 & 0,87 & 0,86 & 0,85 & 0,84 & 0,83 & 0,83 & 0,85 & Non-basis \\
13 & 0,07 & 0,07 & 0,07 & 0,07 & 0,07 & 0,07 & 0,07 & 0,07 & Non-basis \\
14 & 1,14 & 1,15 & 1,16 & 1,17 & 1,16 & 1,18 & 1,19 & 1,16 & Basis \\
15 & 1,44 & 1,42 & 1,45 & 1,45 & 1,44 & 1,44 & 1,45 & 1,44 & Basis \\
16 & 1,30 & 1,22 & 1,24 & 1,22 & 1,22 & 1,22 & 1,22 & 1,23 & Basis \\
17 & 1,15 & 1,13 & 1,14 & 1,14 & 1,12 & 1,10 & 1,10 & 1,12 & Basis \\
\hline
\end{tabular}

Sumber: Data diolah, 2019

Bedasarkan hasil analisis LQ pada tahun 2011 sampai tahun 2017 terdapat 6 sektor yang memiliki nilai lebih dari 1 (LQ > 1). Dari perhitungan LQ diatas dapat dilihat bahwa sektor pertanian, kehutanan, dan perikanan yang mempunyai nilai rata-rata LQ sebesar 1,53 persen. Sektor kedua adalah sektor jasa pendidikan, yaitu dengan nilai rata-rata LQ sebesar 1,44 persen, ketiga sektor jasa kesehatan dan kegiatan sosial yaitu dengan nilai rata-rata LQ sebesar 1,23 persen. Keempat adalaha sektor administrasi pemerintahan, pertahanan dan jaminan sosial wajib yaitu dengan nilai rata-rata LQ 
sebesar 1,16 persen. Di posisi kelima adalah sektor industri pengolahan yaitu dengan nilai rata-rata LQ sebesar 1,12 persen. Sektor terakhir yang masuk kedalam sektor basis adalah sektor jasa lainnya yaitu dengan nilai rata-trata LQ sebesar 1,12 persen. Selain keenam sektor basis diatas sisanya adalah sektor yang tidak masuk kedalam sektor basis alias sektor non basis yang berjumlah 11 sektor. Selain keenam sektor basis diatas sisanya adalah sektor yang tidak masuk kedalam sektor basis alias sektor non basis yang berjumlah 11 sektor. Dari semua 11 sektor ini mempunyai nilai rata-rata LQ nya dibawah angka satu.

\section{Analisis sektor potensial ekonomi wilayah Kabupaten Batanghari}

Metode shift share digunakan untuk mengamati struktur perekonomian dan pergeseran dengan cara menekankan pada pertumbuhan sektor di kabupaten Batanghari di bandingkan dengan sektor yang sama pada Provinsi Jambi, Sektor ekonomi unggulan adalah sektor yang memiliki nilai Nij dan Cij positif. Hasil analisis tentang sektor unggulan dan potensial untuk menunjang pertumbuhan wilayah Kabupaten Batanghari dicantumkan pada tabel 2. Selanjutnya pengaruh pertumbuhan provinsi (N) tidak terdapat sektor di Kabupaten Batanghari yang bernilai negatif, artinya sektor-sektor di Kabupaten Batanghari tumbuh lebih cepat dari pada pertumbuhan Provinsi Jambi. Dari Tujuh belas sektor, sektor pertanian, kehutanan, dan perikanan menjadi sektor yang tercepat pertumbuhannya dibandingkan dengan pertumbuhan Provinsi karena memiliki nilai $\mathrm{N}$ terbesar 1.211.634 diikuti oleh sektor pertambangan dan penggalian dengan nilai $\mathrm{N}$ sebesar 413.630. Kemudian yang ketiga tercepat adalah oleh Industri Pengolahan dengan nilai $\mathrm{N}$ sebesar 384.850 .

Tabel 2 Analisis shift share sektor unggulan di Kabupaten Batanghari

\begin{tabular}{ccrrr}
\hline No & $\begin{array}{c}\text { Komponen } \\
\text { Pertumbuhan } \\
\text { Kabupaten } \\
\text { Nij }\end{array}$ & $\begin{array}{c}\text { Komponen } \\
\text { Bauran } \\
\text { Industri } \\
\text { Mij }\end{array}$ & $\begin{array}{c}\text { Komponen } \\
\text { Keunggulan } \\
\text { Kompetitif } \\
\text { Cij }\end{array}$ & PDRB \\
\cline { 2 - 5 } & \multicolumn{2}{c}{ (Juta Rupiah) } & Dij \\
\hline 1 & 1.211 .634 & 278315,73 & $-380025,13$ & 1.109 .924 \\
2 & 413.630 & $-225617,09$ & 368763,31 & 556.776 \\
3 & 384.850 & $-84065,62$ & 18656,06 & 319.441 \\
4 & 1.311 & 655,72 & 74,14 & 2.041 \\
5 & 2.758 & $-1355,78$ & 613,85 & 2.016 \\
6 & 180.021 & 158688,13 & $-71778,18$ & 266.931 \\
7 & 212.542 & 96653,51 & $-36814,9$ & 272.380 \\
8 & 45.393 & 17098,67 & $-15954,88$ & 17.536 \\
9 & 9.279 & 6708,28 & 1433,31 & 101.744 \\
10 & 79.778 & 31685,56 & $-9719,44$ & 58.168 \\
11 & 56.487 & 12232,53 & $-10551,34$ & 22.769 \\
12 & 41.293 & $-11334,37$ & $-7189,1$ & 1.945 \\
13 & 2.399 & $-565,78$ & 112,02 & 139.235 \\
14 & 116.889 & $-2065,35$ & 24411,59 & 137.484 \\
15 & 144.752 & $-17668,49$ & 10400,83 & 55.566 \\
16 & 37.147 & 26125,61 & $-7706,64$ & 31.041 \\
\hline 17 & 35.509 & $-1097,12$ & $-3371,2$ & \\
\hline
\end{tabular}

Sumber: Data diolah, 2019

Berdasarkan hasil analisis komponen pertumbuhan proporsional (M), sebanyak 9 sektor dari sektor pertumbuhan proporsional bernilai positif yang di kategorikan maju. 
Dan adapun sektor di Kabupaten Batanghari yang lebih maju tersebut yaitu sektor pertanian, kehutanan, dan perikanan; sektor pengadaan listrik dan gas; sektor konstruksi; sektor perdagangan besar dan eceran; reparasi mobil dan sepeda motor; sektor transportasi dan pergudangan; sektor penyediaan akomodasi dan makan minum; sektor informasi dan komunikasi; sektor jasa keuangan dan asuransi dan sektor jasa kesehatan dan kegiatan sosial. Sedangkan untuk sektor yang paling maju adalah sektor pertanian, kehutanan, dan perikanan yaitu dengan nilai M sebesar 278.315,73.

Berdasarkan alat analisis komponen Pertumbuhan Pangsa Wilayah atau Keunggulan Komperatif (C) Berdasarkan tabel di atas, dari 17 sektor di Kabupaten Batanghari sebanyak 8 sektor di Kabupaten Batanghari memiliki daya saing. Hal tersebut dapat dilihat pada $\mathrm{C}$ yang bernilai positif. Sektor yang memiliki daya saing tertinggi yaitu sektor pertambangan dan penggalian, hal tersebut dapat dilihat pada tabel di atas nilai C sebesar 368.763,31.

\section{Analisis sektor unggulan Kabupaten Batanghari}

Menurut Tumenggung (1996) sektor unggulan adalah sektor yang memiliki komperatif dan keunggulan kompetitif dengan produk sektor sejenis dari daerah lain serta memberikan nilai manfaat yang besar. Suatu daerah akan mempunyai sektor unggulan apabila daerah tersebut dapat memenangkan persaingan pada sektor yang sama dengan daerah lain sehingga dapat mrnghasilkan ekspor (Suyatno, 2000). Analisis sektor unggulan dilakukan dengan menggabungkan antara hasil analisis sektor basis (LQ) dengan analisis sektor potensial (shift-share) seperti yang dijelaskan pada Tabel 3.

Tabel 3. Penentuan sektor unggulan Kabupaten Batanghari

\begin{tabular}{|c|c|c|c|c|}
\hline \multirow{2}{*}{ Sektor } & \multirow{2}{*}{ LQ } & \multicolumn{2}{|c|}{ Shift share } & \multirow{2}{*}{ Klasifikasi } \\
\hline & & Mij & $\mathbf{C i j}$ & \\
\hline 1 & Basis & Maju & Tidak kompetitif & Tidak unggulan \\
\hline 2 & Non-basis & Tidak maju & Kompetitif & Tidak unggulan \\
\hline 3 & Basis & Tidak maju & Kompetitif & Unggulan \\
\hline 4 & Non-basis & Maju & Kompetitif & Tidak unggulan \\
\hline 5 & Non-basis & Tidak maju & Kompetitif & Tidak unggulan \\
\hline 6 & Non-basis & Maju & Tidak kompetitif & Tidak unggulan \\
\hline 7 & Non-basis & Maju & Tidak kompetitif & Tidak unggulan \\
\hline 8 & Non-basis & Maju & Tidak kompetitif & Tidak unggulan \\
\hline 9 & Non-basis & Maju & Kompetitif & Tidak unggulan \\
\hline 10 & Non-basis & Maju & Tidak kompetitif & Tidak unggulan \\
\hline 11 & Non-basis & Maju & Tidak kompetitif & Tidak unggulan \\
\hline 12 & Non-basis & Tidak maju & Tidak kompetitif & Tidak unggulan \\
\hline 13 & Non-basis & Tidak maju & Kompetitif & Tidak unggulan \\
\hline 14 & Basis & Tidak maju & Kompetitif & Unggulan \\
\hline 15 & Basis & Tidak maju & Kompetitif & Unggulan \\
\hline 16 & Basis & Maju & Tidak kompetitif & Tidak unggulan \\
\hline 17 & Basis & Tidak maju & Tidak kompetitif & Tidak unggulan \\
\hline
\end{tabular}

Sumber: Data diolah, 2019

\section{Analisis sektor pertanian, kehutanan dan perikanan}

Berdasarkan hasil LQ, sektor pertanian menunjukan nilai rata-rata LQ yang sangat besar yaitu 1,53, hal ini berarti sektor ini termasuk sector basis. Hasil penghitungan Shift Share sektor pertanian nilai Komponen Mij sebesar 278.315,73 menunjukkan sektor ini merupakan sektor yang maju (tumbuh cepat) di tingkat Provinsi 
Jambi. Sedangkan nilai Komponen Cij sebesar -380025,13, berarti bahwa sektor pertanian mempunyai daya saing yang melambat, karena pertumbuhannya lebih lambat dari pada Provinsi. Dan secara klasifikasi sektor pertanian, kehutanan dan perikanan tidak termasuk kedalam sektor unggulan di Kabupaten Batanghari.

\section{Analisis sektor pertambangan dan penggalian}

Berdasarkan analisis LQ, sektor ini menunjukkan nilai LQ rata-rata sebesar 0,58. Hasil Penghitungan Shift Share sektor pertambangan dan penggalian nilai komponen Mij sebesar -225.617. Sedangkan nilai komponen Cij sebesar 368.763,31. Berdasarkan uraian diatas, dapat disimpulkan bahwa sektor pertambangan dan penggalian tidak termasuk ke dalam sektor unggulan di Kabupaten Batanghari.

\section{Analisis sektor industri pengolahan}

Berdasarkan analisis LQ, sektor ini menunjukkan nilai LQ rata-rata sebesar 1,12. Hasil penghitungan Shift Share sektor Industri Pengolahan nilai komponen Mij sebesar 84.065,62. Sedangkan nilai komponen Cij sebesar 18.656,06. Berdasarkan uraian diatas, dapat disimpulkan bahwa sektor industri pengolahan termasuk ke dalam sektor unggulan di Kabupaten Batanghari.

\section{Analisis sektor pengadaan listrik dan gas}

Berdasarkan hasil LQ, sektor pengadaan listrik dan gas menunjukan nilai ratarata LQ yang sangat besar yaitu 0,94. Hasil penghitungan Shift Share sektor pengadaan listrik dan gas nilai komponen Mij sebesar 655. Sedangkan nilai komponen Cij sebesar 74,14 . Berdasarkan uraian diatas, dapat disimpulkan bahwa sektor pengadaan listrik dan gas dapat digolongkan sebagai sektor tidak unggulan di Kabupaten Batanghari.

\section{Analisis sektor pengadaan air, pengelolaan sampah, limbah dan daur ulang}

Berdasarkan hasil LQ, sektor pengadaan air, pengelolaan sampah, limbah dan daur ulang menunjukan nilai rata-rata LQ yang sangat besar yaitu 0,60. Hasil penghitungan Shift Share sektor pengadaan air, pengelolaan sampah, limbah dan daur ulang nilai komponen Mij sebesar -1.355,. Sedangkan nilai komponen Cij sebesar 613,85. Dan secara klasifikasi sektor pengadaan air, pengelolaan sampah, limbah dan daur ulang tidak termasuk kedalam sektor unggulan di Kabupaten Batanghari.

\section{Analisis sektor kontruksi}

Berdasarkan hasil LQ, sektor kontruksi menunjukan nilai rata-rata LQ yang besar yaitu 0,97. Hasil penghitungan Shift Share sektor kontruksi nilai komponen Mij sebesar 158.688,13. Sedangkan nilai komponen Cij sebesar -71.778,18. Dan secara klasifikasi sektor kontruksi tidak termasuk kedalam sektor unggulan di Kabupaten Batanghari.

\section{Analisis sektor perdagangan besar dan eceran; reparasi mobil dan sepeda motor}

Berdasarkan hasil LQ, sektor perdagangan besar dan eceran; reparasi mobil dan sepeda motor menunjukan nilai rata-rata LQ yang besar yaitu 0,80 . Hasil penghitungan Shift Share sektor perdagangan besar dan eceran; reparasi mobil dan sepeda motor nilai komponen Mij sebesar 96.653. Sedangkan nilai komponen Cij sebesar -36.814,90 berarti bahwa sektor perdagangan besar dan eceran; reparasi mobil dan sepeda motor mempunyai daya saing yang menurun karena mempunyai nilai negatif, karena pertumbuhannya lebih lambat dari pada Provinsi. Dan secara klasifikasi sektor perdagangan besar dan eceran; reparasi mobil dan sepeda motor tidak termasuk kedalam sektor unggulan di Kabupaten Batanghari. 


\section{Analisis sektor transportasi dan pergudangan transportasi dan pergudangan}

Berdasarkan hasil LQ, sektor transportasi dan pergudangan menunjukan nilai rata-rata LQ yang besar yaitu 0,48. Hasil penghitungan Shift Share sektor transportasi dan pergudangan nilai komponen Mij sebesar 17.098,67. Sedangkan nilai komponen Cij sebesar $-15.954,88$ berarti bahwa sektor transportasi dan pergudangan mempunyai daya saing yang menurun karena mempunyai nilai negatif, karena pertumbuhannya lebih lambat dari pada Provinsi Jambi. Dan secara klasifikasi sektor transportasi dan pergudangan transportasi dan pergudangan tidak termasuk kedalam sektor unggulan di Kabupaten Batanghari.

\section{Analisis sektor penyediaan akomodasi dan makan minum}

Berdasarkan hasil LQ, sektor penyediaan akomodasi dan makan minum menunjukan nilai rata-rata LQ yang besar yaitu 0,33. Hasil penghitungan Shift Share sektor penyediaan akomodasi dan makan minum nilai komponen Mij sebesar 6.708,. Sedangkan nilai komponen $\mathrm{Cij}$ sebesar 1.433,31 berarti bahwa sektor penyediaan akomodasi dan makan minum mempunyai daya saing yang meningkat karena mempunyai nilai positif, karena pertumbuhannya lebih cepat dari pada Provinsi. Dan secara klasifikasi sektor penyediaan akomodasi dan makan minum tidak termasuk kedalam sektor unggulan di Kabupaten Batanghari.

\section{Analisis sektor informasi dan komunikasi}

Berdasarkan hasil LQ, sektor informasi dan komunikasi menunjukan nilai ratarata LQ yang besar yaitu 0,80. Hasil penghitungan Shift Share sektor informasi dan komunikasi nilai komponen Mij sebesar 31.685. Sedangkan nilai komponen Cij sebesar -9.719,44 berarti bahwa sektor informasi dan komunikasi mempunyai daya saing yang menurun karena mempunyai nilai negatif, karena pertumbuhannya lebih lambat dari pada Provinsi. Dan secara klasifikasi sektor informasi dan komunikasi tidak termasuk kedalam sektor unggulan di Kabupaten Batanghari.

\section{Analisis sektor jasa keuangan dan asuransi}

Berdasarkan analisis LQ, sektor jasa keuangan dan asuransi menunjukkan nilai LQ rata-rata sebesar 0,83. Hasil penghitungan Shift Share sektor jasa keuangan dan asuransi nilai komponen Mij sebesar 12.232,53. Sedangkan nilai komponen Cij sebesar $-10.551,34$ berarti bahwa sektor ini sebagai sektor yang daya saingnya menurun, karena pertumbuhannya lebih lambat dari pada pertumbuhan di Provinsi. Dan secara klasifikasi sektor jasa keuangan dan asuransi tidak termasuk kedalam sektor unggulan di Kabupaten Batanghari.

\section{Analisis sektor real estate}

Berdasarkan analisis LQ, sektor real estate menunjukkan nilai LQ rata-rata sebesar 0,85. Hasil penghitungan Shift Share sektor real estate nilai komponen Mij sebesar -11.334,37 menunjukkan sektor ini merupakan sektor tidak maju. Sedangkan nilai komponen Cij sebesar -7.189,10 berarti bahwa sektor ini sebagai sektor yang daya saingnya menurun, karena pertumbuhannya lebih lambat dari pada pertumbuhan di Provinsi. Dan secara klasifikasi sektor real estate tidak termasuk kedalam sektor unggulan di Kabupaten Batanghari.

\section{Analisis sektor jasa perusahaan}

Berdasarkan hasil LQ, sektor jasa perusahaan menunjukan nilai rata-rata LQ yang besar yaitu 0,07 hal ini berarti sektor ini termasuk sektor non-basis. Hasil penghitungan Shift Share sektor jasa perusahaan nilai komponen Mij sebesar -565,78, menunjukkan sektor ini merupakan sektor yang tidak maju. Sedangkan nilai komponen 
Cij sebesar 112,02 berarti bahwa sektor jasa perusahaan mempunyai daya saing yang meningkat karena mempunyai nilai positif, karena pertumbuhannya lebih cepat dari pada Provinsi. Dan secara klasifikasi sektor jasa perusahaan tidak termasuk kedalam sektor unggulan di Kabupaten Batanghari.

\section{Analisis sektor pemerintahan, pertahanan dan jaminan sosial wajib}

Berdasarkan hasil LQ, sektor pemerintahan, pertahanan dan jaminan sosial wajib menunjukan nilai rata-rata LQ yang besar yaitu 1,16. Hasil penghitungan Shift Share sektor pemerintahan, pertahanan dan jaminan sosial wajib nilai komponen Mij sebesar 2.065,. Sedangkan nilai komponen Cij sebesar 24411,59 berarti bahwa sektor pemerintahan, pertahanan dan jaminan sosial wajib mempunyai daya saing yang meningkat karena mempunyai nilai positif, karena pertumbuhannya lebih cepat dari pada Provinsi. Dan secara klasifikasi analisis sektor pemerintahan, pertahanan dan jaminan sosial wajib termasuk kedalam sektor unggulan di Kabupaten Batanghari.

\section{Analisis sektor jasa pendidikan}

Berdasarkan hasil, sektor jasa pendidikan menunjukan nilai rata-rata LQ yang besar yaitu 1,44. Hasil penghitungan Shift Share sektor jasa pendidikan nilai komponen Mij sebesar -17.668,49. Sedangkan nilai komponen Cij sebesar 10.400,83 berarti bahwa sektor jasa pendidikan mempunyai daya saing yang meningkat karena mempunyai nilai positif, karena pertumbuhannya lebih cepat dari pada Provinsi. Dan secara klasifikasi sektor jasa pendidikan termasuk kedalam sektor unggulan di Kabupaten Batanghari.

\section{Analisis sektor jasa kesehatan dan kegiatan sosial}

Berdasarkan hasil, sektor jasa kesehatan dan kegiatan sosial menunjukan nilai rata-rata LQ yang besar yaitu 1,27. Hasil penghitungan Shift Share sektor jasa kesehatan dan kegiatan sosial nilai komponen Mij sebesar 26.125,61. Sedangkan nilai komponen $\mathrm{Cij}$ sebesar -7.706,64 berarti bahwa sektor jasa kesehatan dan kegiatan sosial mempunyai daya saing yang menurun karena mempunyai nilai negatif, karena pertumbuhannya lebih lambat dari pada Provinsi. Dan secara klasifikasi sektor kesehatan dan kegiatan sosial tidak termasuk kedalam sektor unggulan di Kabupaten Batanghari.

\section{Analisis sektor jasa lainnya}

Berdasarkan hasil LQ, sektor jasa lainnya menunjukan nilai rata-rata LQ sebesar yaitu 1,12.. Hasil penghitungan Shift Share sektor jasa lainnya nilai komponen Mij sebesar -1.097,12. Sedangkan nilai komponen Cij sebesar $-3.371,20$ berarti bahwa sektor jasa lainnya mempunyai daya saing yang menurun karena mempunyai nilai negatif, karena pertumbuhannya lebih lambat dari Provinsi. Dan secara klasifikasi sektor jasa lainnya tidak termasuk kedalam sektor unggulan di Kabupaten Batanghari.

\section{KESIMPULAN DAN SARAN}

\section{Kesimpulan}

Hasil analisis LQ menunjukkan bahwa sektor-sektor basis di Kabupaten Batanghari adalah sektor pertanian, kehutanan, dan perikanan; sektor industri pengolahan; sektor administrasi pemerintahan, pertahanan dan jaminan sosial wajib; sektor jasa pendidikan; sektor jasa kesehatan dan kegiatan sosial dan sektor jasa lainnya.

Hasil analisis Shift Share, dari pengaruh pertumbuhan Provinsi (N), dari 17 sektor yang ada semuanya bernilai positif, sektor pertanian, kehutanan, dan perikanan menjadi sektor yang paling cepat pertumbuhannya dibandingkan dengan pertumbuhan Provinsi karena memiliki nilai Nij sebesar 1.211.634 diikuti oleh sektor pertambangan dan penggalian dengan nilai Nij 413.630. Sektor-sektor yang maju di Kabupaten 
Batanghari adalah sektor pertanian, kehutanan, dan perikanan; sektor pengadaan listrik dan gas; sektor konstruksi; sektor perdagangan besar dan eceran; reparasi mobil dan sepeda motor; sektor transportasi dan pergudangan; sektor penyediaan akomodasi dan makan minum; sektor informasi dan komunikasi; sektor jasa keuangan dan asuransi dan sektor jasa kesehatan dan kegiatan sosial. Sektor-sektor yang memiliki daya saing di Kabupaten Batanghari adalah sektor pertambangan dan penggalian; sektor industri pengolahan; sektor pengadaan listrik dan gas; sektor pengadaan air, pengelolaan sampah, limbah dan daur ulang; sektor penyediaan akomodasi dan makan minum; sektor jasa perusahaan; sektor administrasi pemerintahan, pertahanan dan jaminan sosial wajib dan jasa pendidikan.

Hasil dari gabungan analisis yaitu LQ dan Shift Share, yaitu sektor industri pengolahan; sektor administrasi pemerintahan, pertahanan dan jaminan sosial wajib dan sektor jasa pendidikan. Ketiga sektor ini adalah sektor unggulan karena memberikan kontribusi yang paling besar terhadap PDRB Kabupaten Batanghari.

\section{Saran}

Pemerintah Daerah Kabupaten Batanghari dalam menentukan kebijakan kebjakan perekonomian yaitu dengan memprioritaskan sektor-sektor basis, kompetitif dan berdaya saing serta sektor yang maju dan tumbuh dengan pesat dan juga tidak mengabaikan sektor dan sub-sektor lainnya dalam perencanaan dan pelaksanaan pembangunan di Kabupaten Batanghari.

Sektor industri pengolahan; sektor administrasi pemerintahan, pertahanan dan jaminan sosial wajib dan sektor jasa pendidikan sebagai sektor unggulan dan memiliki kontribusi terbesar dalam perekonomian wilayah Kabupaten Batanghari perlu mendapatkan prioritas pengembangan, Pemerintah Kabupaten Batanghari diharapkan meningkatkan ketiga sektor ini menjadi sektor yang maju. Peningkatan kualitas dan kuantitas produksi dapat dilakukan dengan memperkuat kelembagaan kelompok tani dan alat-alat modren dalam bidang pertanian lainya untuk menerapkan sapta usaha tani yang lebih baik lagi.

\section{DAFTAR PUSAKA}

Arsyad. (1999). Ekonomi pembangunan. STIE YKPN: Yogyakarta.

P Parmadi, E Emilia, Z Zulgani. (2018). Daya saing produk unggulan sektor pertanian Indonesia dalam hubungannya dengan pertumbuhan Ekonomi, Jurnal Paradigma Ekonomika 13 (2), 77-86

Sjafrizal. (2008). Ekonomi regional, teori dan aplikasi. Boduose Media: Padang

Soepomo. (1993). Analisisi shift share perkembangan Cian Penerapan Jurnal Ekonomi

Dan Bisnis. Jurnal. BPEE UGM: Yogyakarta

Sukirno. (2008). Ekonomi pembangunan. LP FEUI: Jakarta

Suyatno. (2000). Analisa econimic base terhadap pertumbuhan ekonomi daerah tingkat

II Wonogiri. Jurnal Ekonomi Pembangunan. 1(2), 144-159. UMS: Surakarta

Tarigan, R. (2004). Perencanaan pembangunan wilayah. Bumi Aksara: Jakarta.

Tarigan, R. (2009). Ekonomi regional teori dan aplikasi. Edisi Revisi. PT. Bumi Aksara: Jakarta

Todaro. (2000). Pembangunan ekonomi di dunia ketiga. Erlangga: Jakarta

Tumenggung. (1996). Gagasan dan kebijaksanaan pembangunan ekonomi terpadu

(Kawasan Timur Indonesia). Direktorat Bina Tata Perkotaan dan Pedesaan

Dirjen Cipta Karya Departemen PU: Jakarta

Y Yusral, J Junaidi, A Bhakti. (2015). Klasifikasi Pertumbuhan, Sektor Basis dan Kompetitif Kota Jambi, Jurnal Perspektif Pembiayaan dan Pembangunan

Daerah 2 (4), 209-216

Yuwono. (1999). Penentuan sektor unggulan daerah menghadapi implementasi UU No. 22/1999. Jurnal Ekonomi Pembangunan. 7(2). 